\title{
Soil moisture index estimation from Landsat 8 images for prediction and monitoring landslide occurrences in Ulu Kelang, Selangor, Malaysia
}

\author{
Noraisyah Tajudin', Norsuzila Ya'acob ${ }^{2}$, Darmawaty Mohd Ali ${ }^{3}$, Nor Aizam Adnan ${ }^{4}$ \\ ${ }^{1,2,3}$ Wireless Communication Technology (WiCoT), Faculty of Electrical Engineering, Universiti Teknologi MARA, \\ Selangor, Malaysia \\ ${ }^{4}$ Faculty of Architecture, Planning and Surveying, Universiti Teknologi MARA, Selangor, Malaysia
}

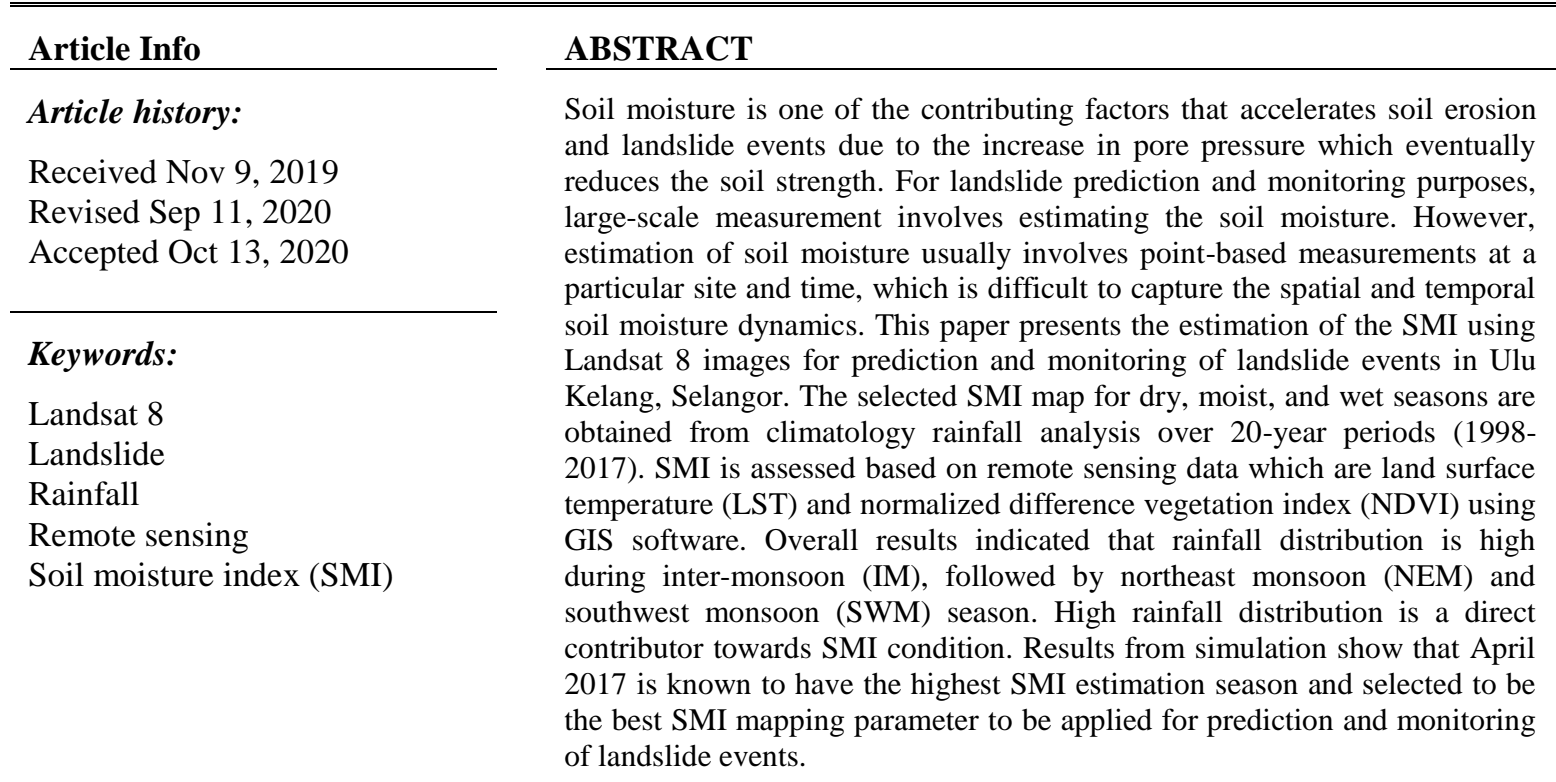

This is an open access article under the CC BY-SA license.

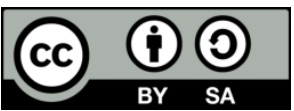

\section{Corresponding Author:}

Norsuzila Ya'acob

Wireless Communication Technology (WiCoT)

Faculty of Electrical Engineering

Universiti Teknologi MARA, 40450 UiTM Shah Alam, Selangor, Malaysia

Email: norsuzila@uitm.edu.my

\section{INTRODUCTION}

Rainfall has been known as the main factor for most of the landslide events in the region of high seasonal rainfalls [1-4]. Any given rainfall event will cause an increase of pore water pressure within the soil on the area. Whenever a slope filled with water, the fluid pressure will provide a block of flexibility which reduces the resistance of movement and eventually causing the slope to fail. This condition can get even worse due to the soil conditions of the affected area [5-7]. It is important to identify the soil moisture of the area before considering rainfall as the factor that causing the landslide event, especially on deep-seated landslides and terrains with complex hydrological $[8,9]$. Commonly, soil moisture measurement can be estimated by using three methods: in situ measurements, hydrological model, and remote sensing. In situ measurements were the best method among the three which can provide the highest accuracy, but it only 
offers point-based measurement and limited due to high dependencies of installation and maintenance cost. The second method is to obtain variations of continuous soil moisture is through the land surface or hydrological model. Nevertheless, model-based approaches tend to deal with the issue of time drifts, large numbers of reliable data inputs and computationally intensive for large monitoring areas. Therefore, remote sensing and GIS techniques proved to be reliable alternative to soil moisture estimation on a global scale [10-14].

Remote sensing techniques offer a continuous estimation of soil moisture for a large area. For this case-study, soil moisture estimations are referring to the near-surface soil moisture (NSSM), which characterizes the first $5 \mathrm{~cm}$ or less of the topsoil profile. In recent years, remote sensing techniques have been advanced and varied their estimation to make more effective tool for monitoring soil moisture index (SMI) and other related variables such as land surface temperature (LST) and the normalized difference vegetation index (NDVI) [15-17]. LST calculation is defined from thermal emission, while NDVI is estimated based on portions of the electromagnetic spectrum, namely red and near-infrared (NIR) surface reflectance. These methods are sometimes known as optical and thermal infrared of remote sensing. Previous studies were conducted based on passive or active microwave data to estimate the soil water substance in the surface soil layer within 0 to $10 \mathrm{~cm}[18,19]$.

Other usage of these optical and/or thermal data is to indirectly identify soil moisture condition by referring the changes of biophysical factors, such as surface energy balance and vegetation cover, which were affected by the availability of soil water. Results from various studies show a potential in monitoring both root zone and surface of soil moisture by using thermal and/or optical derived from vegetation. Over the years, various vegetation indices have been used to estimate soil moisture and the response of vegetation to the spatial and temporal variations [20-22]. The aim of this study is to estimate the soil moisture index from Landsat 8 images based on dry, moist, and wet seasons. The analysis of SMI condition season is conducted to provide the best SMI mapping parameter in predicting and monitoring of landslide occurrences in Ulu Kelang, Selangor.

\section{RESEARCH METHOD}

\subsection{Study area and data set}

This study was carried out at Ulu Kelang, Selangor which is located at the latitude of $3^{\circ} 12^{\prime} 30^{\prime \prime} \mathrm{N}$ and longitude of $101^{\circ} 45^{\prime} 28^{\prime}$ ' E with a $5 \mathrm{~km}$ distance from Kuala Lumpur city center as shown in Figure 1. Ulu Kelang is a residential area which is known as one of Malaysia's most landslide-prone areas. The average of annual rainfall in Ulu Kelang area is about $2,440 \mathrm{~mm}$. The rainfall distribution mainly based on two monsoon seasons, known as the southwest monsoon (SWM), beginning from May to August and the northeast monsoon (NEM) which is from November to February. In Ulu Kelang, the soil moisture is mostly influenced by rainfall distribution [23-26].

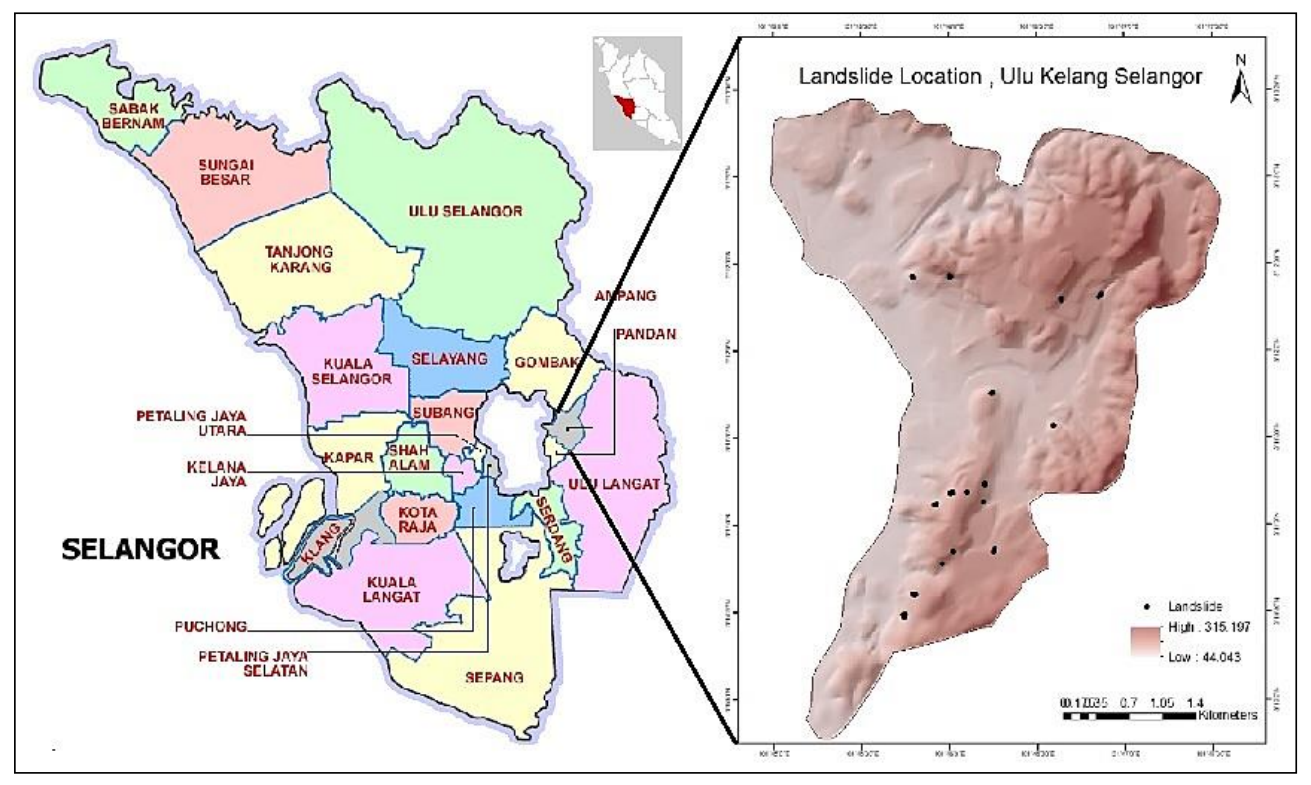

Figure 1. Location of Ulu Kelang, Selangor 
The ground-based measurement rainfall data is used to analyze the climatology of rainfall in Ulu Kelang, Selangor. The rain-gauge data was provided by jabatan pengairan dan saliran (JPS), Ampang. Two rain-gauge stations (JPS Ampang and Genting Kelang) were acquired to represent the rainfall distribution for 20-year periods from 1998 to 2017. The soil moisture index was analyzed from Landsat 8 images were downloaded using USGS Earth Explorer website. Landsat 8 images were selected based on the climatology of rainfall and the availability of cloud free satellite images. The SMI map was produced by using ArcGIS 10.2.2. The selected images are listed in Table 1.

Table 1. Selected Landsat images

\begin{tabular}{ccccc}
\hline Satellite & Date of acquisition & Monsoon Season & Period & Path/row \\
\hline \multirow{3}{*}{ Landsat 8 } & $12 / 2 / 2017$ & NEW & Nov - Feb & \\
& $17 / 4 / 2017$ & IM & Mar - April \& Sept - Oct & $158 / 226$ \\
& $20 / 6 / 2017$ & SWM & May - Aug & \\
\hline
\end{tabular}

\subsection{Methodology}

Figure 2 shows the methodology of the SMI analysis based on Landsat 8 images which were selected from climatology of rainfall analysis for dry (low moisture), moist (medium moisture) and wet (high moisture) seasons. The Landsat 8 images were selected in February, April and June of the year 2017. SMI is calculated based on the combination of the NDVI and LST calculation using (1) [27, 28].

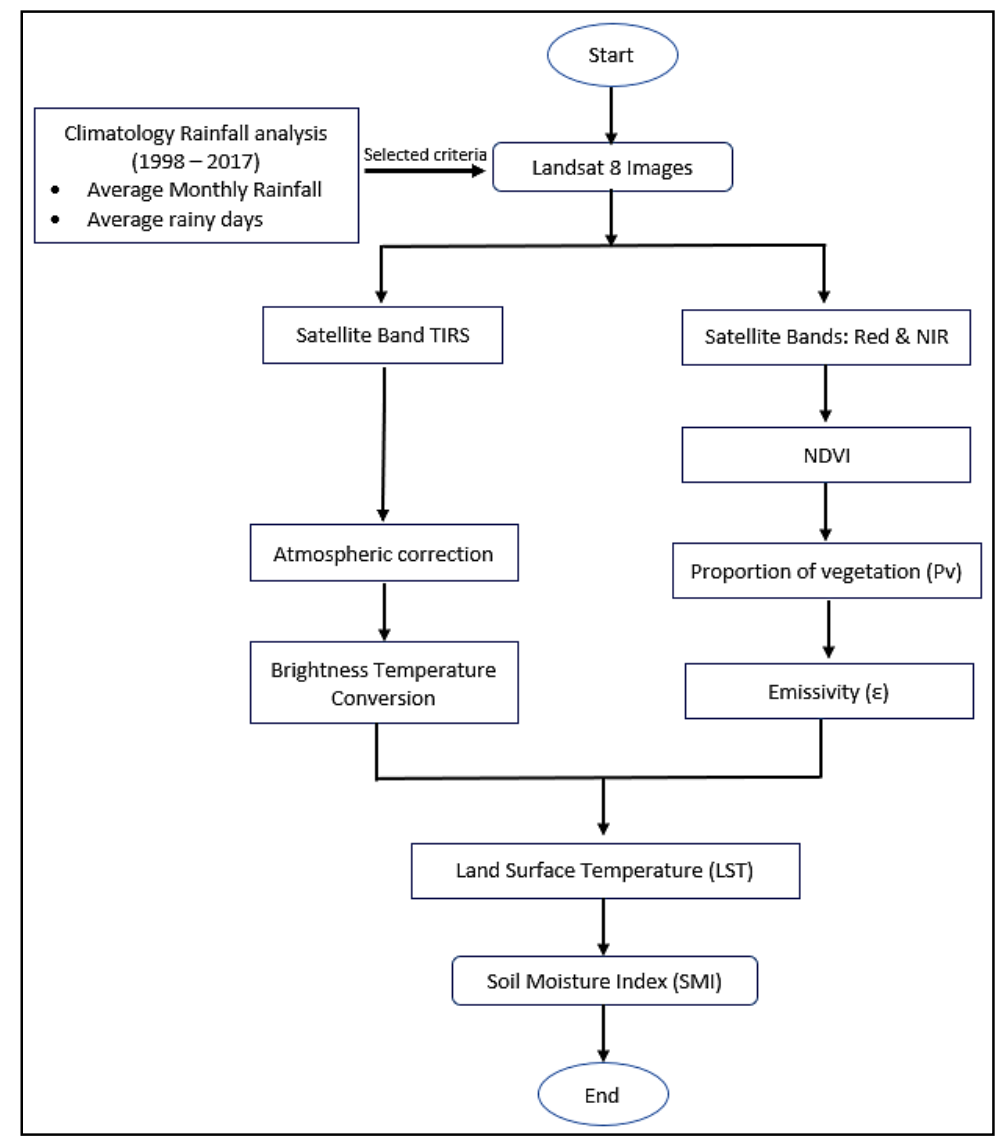

Figure 2. The methodology flowchart of SMI analysis

$$
S M I=\left(L S T_{\max }-L S T\right) /\left(L S T_{\max }-L S T_{\min }\right)
$$

Where, for a given NDVI, LSTmax and LSTmin are the maximum and minimum of surface temperature and the land surface temperature is LST, the surface temperature of a pixel for a given NDVI derived from remote sensing. The calculation of LST is based on the (2). 


$$
L S T=T_{b} /\left[1+\left(\alpha^{*} T_{b} / C_{2}\right) * \ln (\varepsilon)\right]
$$

Where $T_{b}$ in ${ }^{\circ} \mathrm{C}(3)$ is a Satellite brightness Temperature, $\alpha$ is the wavelength of emitted radiance, $C_{2}=$ 1.4388 and $\varepsilon$ as in (4)

$$
\begin{aligned}
& T_{b}=\left(K_{2} /\left(\ln \left(K_{1} / L\right)+1\right)\right)-273.15 \\
& \varepsilon=0.004 * P_{v}+C V
\end{aligned}
$$

where $K_{1}$ is sensor dependent calibration constant 1 (774.8853) and $K_{2}$ is sensor dependent calibration constant 2 (1321.0789), L is Top of Atmosphere (TOA) spectral radiance, $P_{v}(5)$ and $\mathrm{CV}$ is correction value for Landsat Images (0.986).

$$
P_{v}=\left(\left(N D V I-N D V I_{\min }\right) /\left(N D V I_{\max }-N D V I_{\min }\right)\right)^{2}
$$

NDVI is define as the ratio of reflectivity differences between NIR and the Red band to their sum. NDVI is calculated using (6):

$$
N D V I=(N I R-R e d) /(N I R+R e d)
$$

Finally, the SMI analysis was obtained using the raster calculator in ArcGIS 10.2.2. The SMI maps provide a value between 0 and 1 , which is represents the relative amount of soil moisture within the area, 0 indicates the lowest soil moisture and 1 indicates the highest soil moisture on a specific day.

\section{RESULTS AND ANALYSIS}

\subsection{Climatology of rainfall analysis}

Rainfall climatology during the southwest monsoon (SWM) occurs between May-August whereas inter-monsoon (IM) happens in March-April and September-October, while northeast monsoon (NEM) is in November-February. The rainfall data were taken in Ulu Kelang, Selangor using ground-based measurement as in Figure 3.

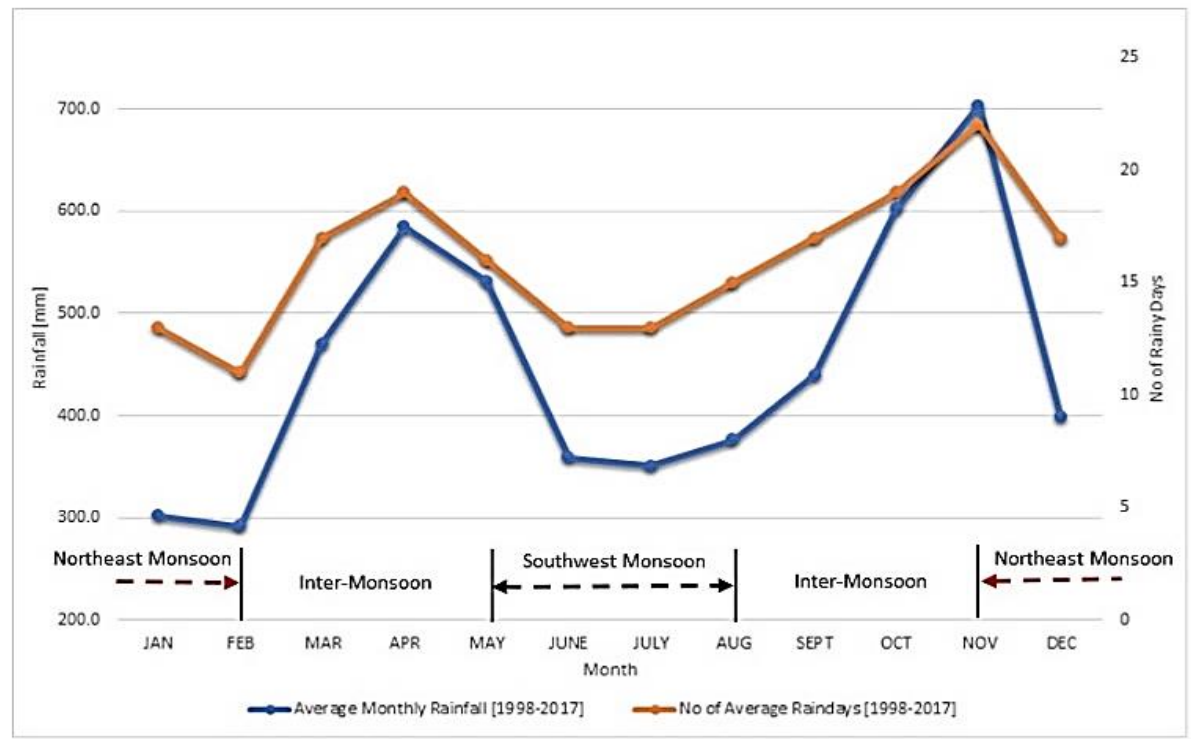

Figure 3. Monsoonal rainfall fluctuation

The monsoonal rainfall fluctuation in Figure 3 is based on average monthly rainfall and rainy days over 20 years (1998-2017). During the SWM season, the highest rainfall was recorded is in the month of May which reached up to $531.2 \mathrm{~mm}$ with 16 rainy days. The following month was in declining trends as the 
rainfall distribution was recorded at $359 \mathrm{~mm}$ (June), $351 \mathrm{~mm}$ (July) and $376 \mathrm{~mm}$ (August) respectively. The rainfall patterns during both IM season shows similarities in receiving high rainfall distribution in April (584.8 mm with 19 rainy days) and October (602.3 $\mathrm{mm}$ with 19 rainy days). During NEM season, Ulu Kelang area received higher rainfall as compared to WSM season. The highest rainfall distribution was recorded in November, which is at $703.1 \mathrm{~mm}$ with 22 rainy days. However, the rainfall pattern for the NEM season is similar to the SWM season whereby the rainfall distribution decreases in the following months: December, January and February. In general, rainfall received during NEM and IM seasons was the highest contributor to its annual rainfall distribution which the rainy months are in November and April. While the dry months are in January and February which happened at the end of NEM season.

\subsection{Soil moisture index (SMI) analysis}

Based on the climatology of rainfall analysis, the months of February, April and June were selected to represent the SMI map as the parameter for landslide events in Ulu Kelang, Selangor. The estimation of normalized difference vegetation index (NDVI) and land surface temperature (LST) are based on essential data for obtaining SMI calculation. The NDVI values range from -1 to 1 where the negative value of vegetation indicates a poor vegetative cover, while the positive value indicates a dense and good vegetative cover. Figures 4(a), 4(b) and 4(c) show the NDVI values for February (-0.03 to 0.56), April (-0.01 to 0.56) and June 2017 (-0.06 to 0.54 ) respectively.

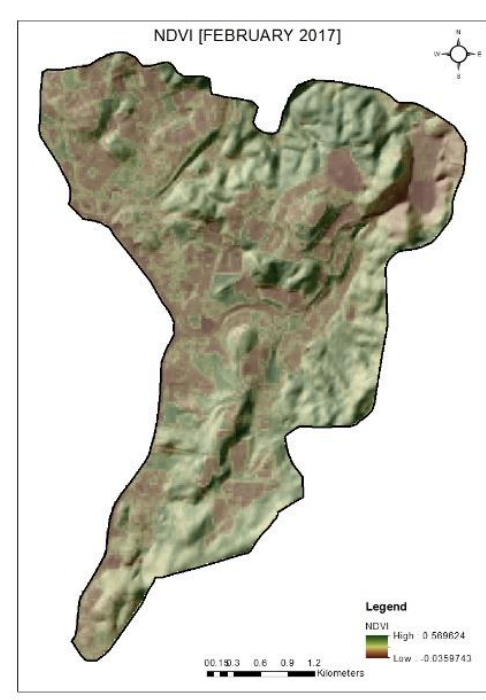

(a)

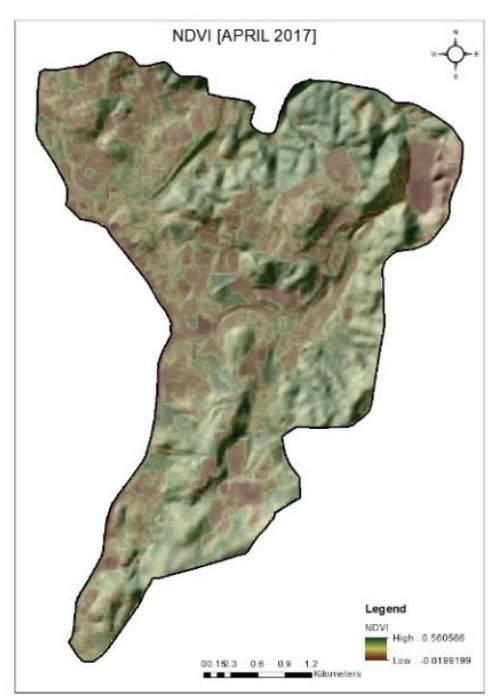

(b)

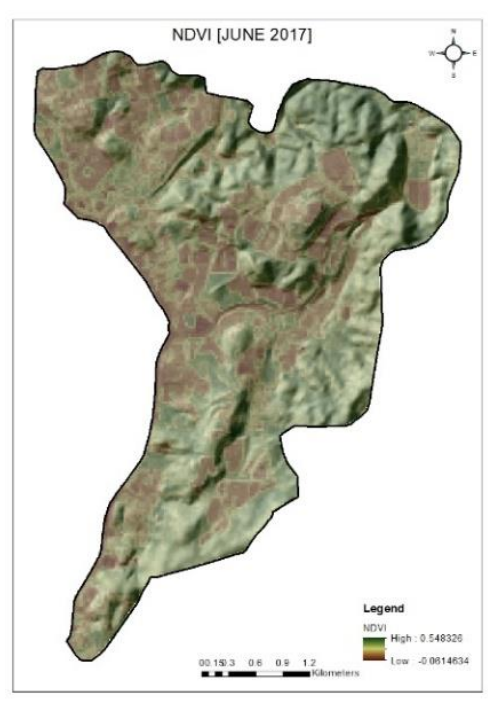

(c)

Figure 4. The normalized difference vegetation index (NDVI) for (a) February 2017, (b) April 2017 and (c) June 2017

While the LST values range for February, April and June 2017 is between $17{ }^{\circ} \mathrm{C}$ to $31.7{ }^{\circ} \mathrm{C}$. The LST map in Figure 5 is classified into four classes, LST less than $22{ }^{\circ} \mathrm{C}$, LST between $22{ }^{\circ} \mathrm{C}$ to $24{ }^{\circ} \mathrm{C}$, LST between $24{ }^{\circ} \mathrm{C}$ to $27{ }^{\circ} \mathrm{C}$ and LST more than $27{ }^{\circ} \mathrm{C}$. The result in Figures 5(a), 5(b) and 5(c) show in April 2017 by $41.47 \%$ of area is estimated as high LST values which is more than $27{ }^{\circ} \mathrm{C}$. Meanwhile the LST estimation in June showed low LST values in most areas.

Figures 6(a), 6(b) and 6(c) show the SMI Map for February, April, and June 2017 respectively. The minimum SMI for all selected months is between 0.000001 to 0.000006 and the maximum SMI is between 0.999997 to 1.00000 . This is in line with SMI indicator which in the range of 0 to 1 . The SMI map is classified into three classes, SMI less than $0.3(<0.3$, dry area), SMI between 0.3 and $0.5(0.3-0.5$, moist area $)$ and SMI more than 0.5 (> 0.5, wet area). The brown spot areas known as dry areas, which indicate the SMI value close to zero was highly affected by water deficit. While the yellow spot areas are identified as moist areas. The SMI value near to 1 is represented by green spot areas which known as the wet area or forest cover and have the highest moisture as compared to the rest of land cover.

Figure 7 shows the total area of SMI classes in February, April and June for the year of 2017. From the analysis, there is a large dry area which is approximately $41 \%\left(6.5349 \mathrm{~km}^{2}\right)$ in February compared to moist $(28 \%)$ and wet area $(31 \%)$. While in April, $17 \%\left(2.709 \mathrm{~km}^{2}\right)$ was identified as dry area, $32 \%$ 
$\left(5.1381 \mathrm{~km}^{2}\right)$ as the moist area and $51 \%\left(8.1882 \mathrm{~km}^{2}\right)$ as the wet area. In June, all SMI classes were within the same percentage where dry area covers $31 \%\left(5.1921 \mathrm{~km}^{2}\right)$, moist area at $33 \%\left(4.9419 \mathrm{~km}^{2}\right)$ and wet area at $36 \%\left(5.9013 \mathrm{~km}^{2}\right)$. Based on the analysis conducted on the selected months, April was found to be the most wet/rainy month compared to February and June. This is due to $83 \%$ of the area in April was covered by moist and wet areas, while in February it was only at $51 \%$ and June at $69 \%$.

Based on these analyses, April is found to be the most wet/rainy season which aligned to the IM season periods of March-April and September-October and also the beginning of NEM in November and December. While June is represented as the moist season for SWM. The month of February is identified as the dry season which indicates the end of NEM season (January and February). However, only one SMI map will be selected to represent the SMI parameter for landslide events. The best selected parameter is based on the SMI map in April as most of the landslide events occur in high SMI value during the rainy season.

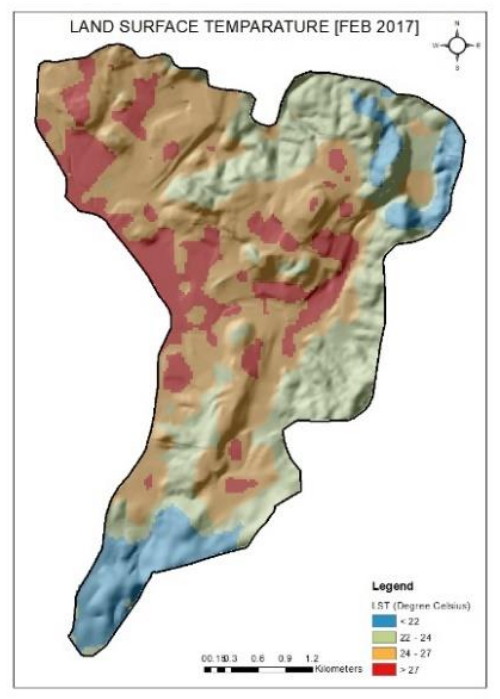

(a)

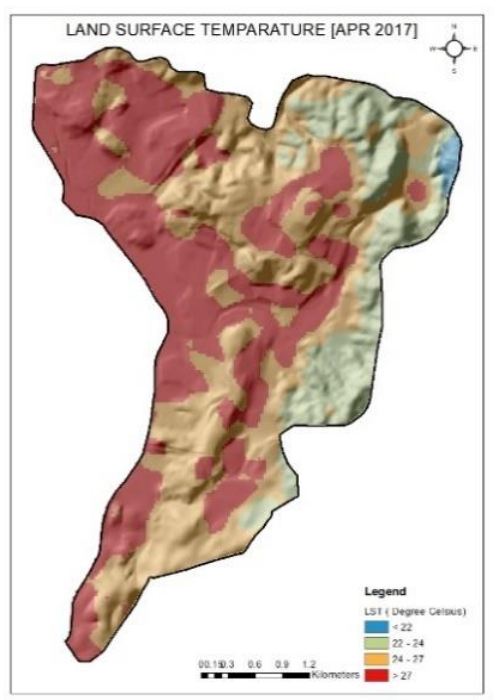

(b)

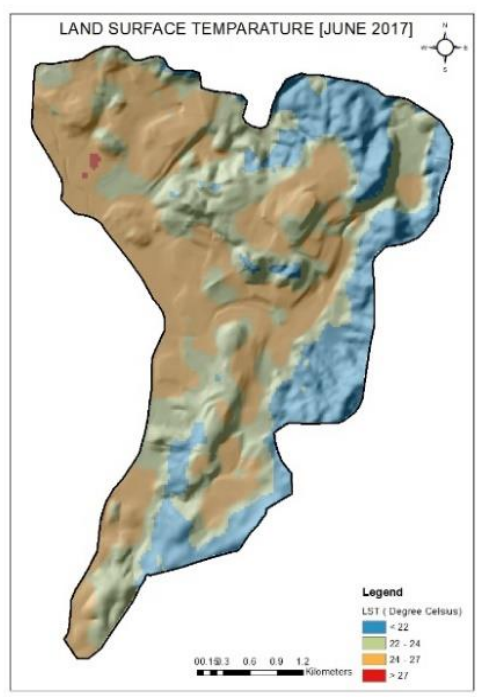

(c)

Figure 5. Land surface temperature (LST) for (a) February 2017, (b) April 2017 and (c) June 2017

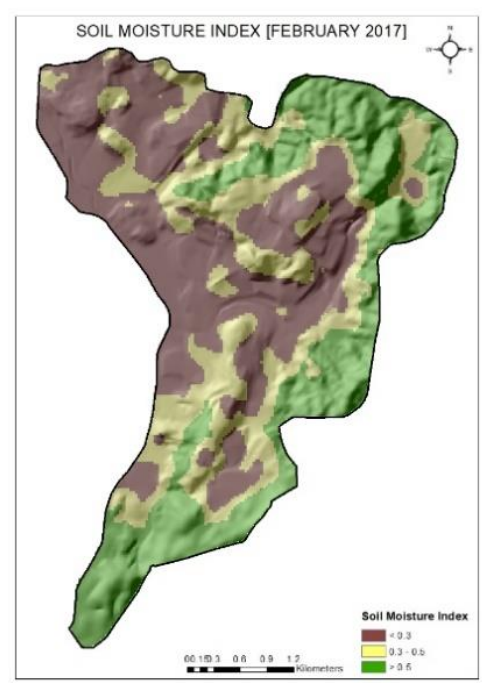

(a)

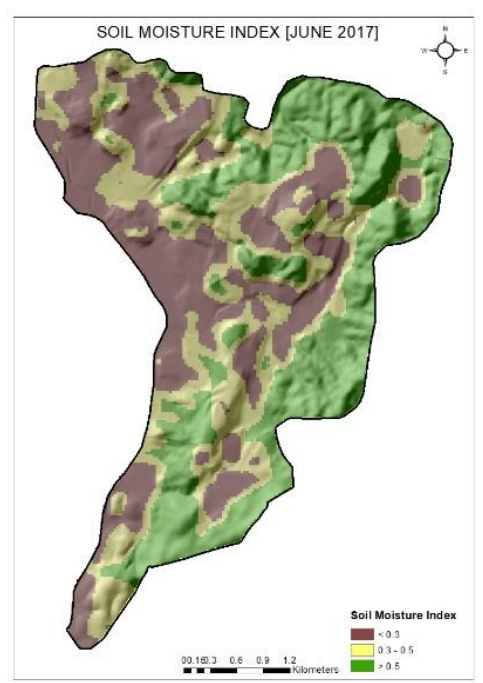

(b)

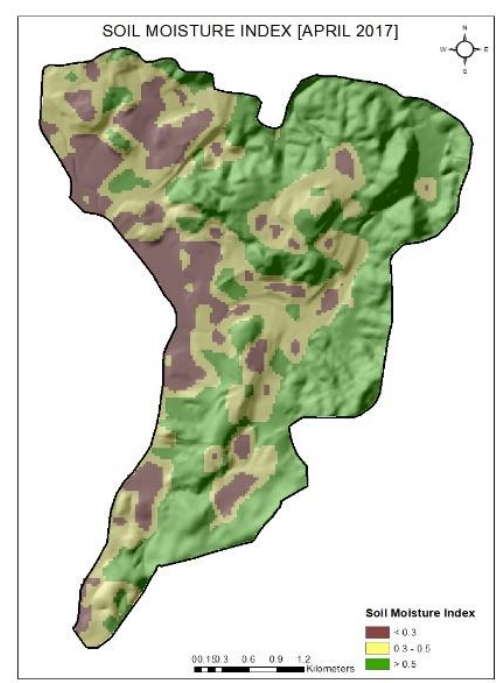

(c)

Figure 6. Soil moisture index for (a) February 2017 (dry season), (b) June 2017 (moist season), and (c) April 2017 (wet season) 


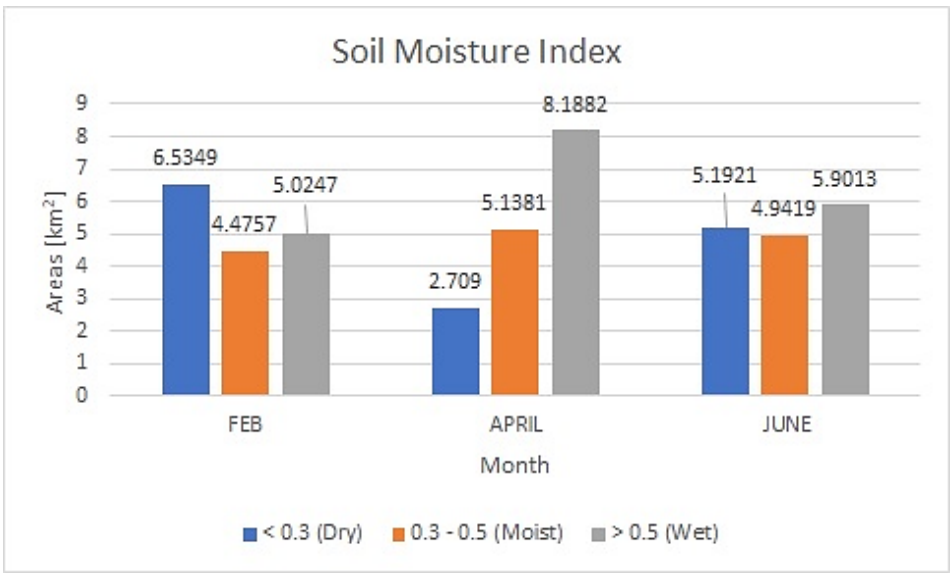

Figure 7. The areas distribution for 3 classes of SMI in February, April and June for the year 2017 at Ulu Kelang, Selangor

\section{CONCLUSION}

Soil moisture was the key parameter to monitor and predict the rainfall-landslide occurrences, especially in hilly areas. The main objective is to generate SMI map estimation, derived from Landsat 8 images by considering the monsoonal season which is influenced by the rainfall distribution. Based on the analysis, results indicated that rainfall distribution is high during IM season followed by NEM season. The month of February, April and June 2017 were selected to present the soil moisture condition for dry, moist, and wet seasons. The highest SMI estimation seasons (wet season) was selected as the SMI parameter in the prediction of landslide occurrences analysis for Ulu Kelang, Selangor.

\section{ACKNOWLEDGEMENTS}

The authors would like to thank Faculty of Electrical Engineering, Universiti Teknologi MARA (UiTM) for their valuable support. This research is partly funded by the Malaysian Government through UiTM under 600/-IRMI/FRGS 5/3 (407/2019). We are grateful to Jabatan Pengairan dan Saliran Malaysia and USGS for providing the Rain gauge data and Landsat 8 Images.

\section{REFERENCES}

[1] M. Irawan, R. H. Virgianto, A. Safril, Munawar, S. T. Gustono, and N. D. Putranto, "Rainfall threshold and soil moisture indexes for the initiation of landslide in Banjarmangu sub-district, central Java, Indonesia," IOP Conference Series: Earth and Environmental Science, vol. 243, no. 1, 2019.

[2] S. J. Matlan, S. Abdullah, R. Alias, and M. Mukhlisin, "Effect of working rainfall and soil water index on slope stability in Ranau, Sabah," Int. J. Civ. Eng. Technol., vol. 9, no. 7, pp. 1331-1341, 2018.

[3] E. Monsieurs, O. Dewitte, and A. Demoulin, "A susceptibility-based rainfall threshold approach for landslide occurrence,” Nat. Hazards Earth Syst. Sci., vol. 19, no. 4, pp. 775-789, 2019, doi: 10.5194/nhess-19-775-2019.

[4] H. Station, "Evaluation of Moisture Level Using Precipitation Indices as a Landslide Triggering Factor -A Study of Coonoor Hill Station," vol. 7, pp. 1-15, 2019, doi: 10.3390/cli7090111.

[5] S. Segoni, A. Rosi, D. Lagomarsino, R. Fanti, and N. Casagli, "Brief communication: Using averaged soil moisture estimates to improve the performances of a regional-scale landslide early warning system," Nat. Hazards Earth Syst. Sci., vol. 18, no. 3, pp. 807-812, 2018, doi: 10.5194/nhess-18-807-2018.

[6] R. L. Ray and J. M. Jacobs, "Relationships among remotely sensed soil moisture, precipitation and landslide events," Nat. Hazards, vol. 43, no. 2, pp. 211-222, 2007.

[7] L. Zhuo, Q. Dai, D. Han, N. Chen, B. Zhao, and M. Berti, "Evaluation of Remotely Sensed Soil Moisture for Landslide Hazard Assessment," IEEE J. Sel. Top. Appl. Earth Obs. Remote Sens., vol. 12, no. 1, pp. 162-173, 2019, doi: 10.1109/JSTARS.2018.2883361.

[8] P. Welikhe, J. E. Quansah, S. Fall, and W. McElhenney, "Estimation of Soil Moisture Percentage Using LANDSAT-based Moisture Stress Index,” J. Remote Sens. GIS, vol. 06, no. 02, pp. 1-5, 2017.

[9] L. Zhuo and D. Han, "Hydrological evaluation of satellite soil moisture data in two basins of different climate and vegetation density conditions," Adv. Meteorol., vol. 2017, pp. 24-28, 2017, doi: 10.1155/2017/1086456.

[10] B. Van Leeuwen, "GIS workflow for continuous soil moisture estimation based on medium resolution satellite data," Agile, 2015,

[11] H. Varikoden and J. V. Revadekar, "Relation Between the Rainfall and Soil Moisture During Different Phases of Indian Monsoon," Pure Appl. Geophys., vol. 175, no. 3, pp. 1187-1196, 2018. 
[12] Y. Zhang, J. Gong, K. Sun, J. Yin, and X. Chen, "Estimation of soil moisture index using multi-temporal Sentinel-1 images over Poyang Lake ungauged zone," Remote Sens., vol. 10, no. 1, pp. 1-19, 2018, doi: 10.3390/rs10010012.

[13] A. Amazirh, et al., "Retrieving surface soil moisture at high spatio-temporal resolution from a synergy between Sentinel-1 radar and Landsat thermal data: A study case over bare soil," Remote Sens. Environ., vol. 211, pp. 321-337, 2018, doi: 10.1016/j.rse.2018.04.013.

[14] M. Lazzari, M. Piccarreta, and S. Manfreda, "The role of antecedent soil moisture conditions on rainfall-triggered shallow landslides," Nat. Hazards Earth Syst. Sci. Discuss., no. December, pp. 1-11, 2018, doi: 10.5194/nhess2018-371.

[15] E. Taktikou, G. Bourazanis, G. Papaioannou, and P. Kerkides, "Prediction of Soil Moisture from Remote Sensing Data," Procedia Eng., vol. 162, pp. 309-316, 2016.

[16] E. S. Mohamed, A. Ali, M. El-Shirbeny, K. Abutaleb, and S. M. Shaddad, "Mapping soil moisture and their correlation with crop pattern using remotely sensed data in arid region," Egypt. J. Remote Sens. Sp. Sci., pp. 1-7, 2019, doi: 10.1016/j.ejrs.2019.04.003.

[17] A. N. Matori, A. Basith, and I. S. H. Harahap, "Study of regional monsoonal effects on landslide hazard zonation in Cameron Highlands, Malaysia," Arab. J. Geosci., vol. 5, no. 5, pp. 1069-1084, 2012.

[18] L. Wang and J. J. Qu, "Satellite remote sensing applications for surface soil moisture monitoring: A review," Front. Earth Sci. China, vol. 3, no. 2, pp. 237-247, 2009.

[19] A. Apriliani, R. Kusumaningrum, S. N. Endah, and Y. Prasetyo, "Suitability analysis of rice varieties using learning vector quantization and remote sensing images," TELKOMNIKA Telecommunication Computing Electronics and Control, vol. 17, no. 3, p. 1290, 2019, doi: 10.12928/telkomnika.v17i3.12234.

[20] Wenfu Peng, Juan Wang, Jie Zhang and You Zhang, "Soil moisture estimation in the transition zone from the Chengdu Plain region to the Longmen Mountains by field measurements and LANDSAT 8 OLI/TIRS-derived indices," Arabian Journal of Geosciences, vol. 13, no. 4, 2020.

[21] Togi Tampubolon, Rita Juliani,Juniar Hutahean and Jeddah Yanti,"Retrieving Surface Soil Moisture from Optical Satellite Imagery over Medan and Surrounding," IOP Conf. Series: Journal of Physics: Conf. Series 1485, 2020.

[22] Mochamad F. G., Ketut W., Agung B. H. and Akihiko K., "Generating soil salinity, soil moisture, soil pH from satellite imagery and its analysis," Information Processing in Agriculture, vol. 7, pp. 294 - 306, 2020, doi: 10.1016/j.inpa.2019.08.003.

[23] M. Mukhlisin, S. J. Matlan, M. J. Ahlan, and M. R. Taha, "Analysis of rainfall effect to slope stability in Ulu Klang, Malaysia," J. Teknol., vol. 72, no. 3, pp. 15-21, 2015.

[24] S. Jeong, A. Kassim, M. Hong, and N. Saadatkhah, "Susceptibility assessments of landslides in Hulu Kelang area using a geographic information system-based prediction model," Sustain., vol. 10, no. 8, 2018, doi: 10.3390/su10082941.

[25] M. L. Lee, K. Y. Ng, Y. F. Huang, and W. C. Li, "Rainfall-induced landslides in Hulu Kelang area, Malaysia," Nat. Hazards, vol. 70, no. 1, pp. 353-375, 2014

[26] N. Ya'acob, N. Tajudin, and A. M. Azize, "Rainfall-landslide early warning system (RLEWS) using TRMM precipitation estimates,” Indones. J. Electr. Eng. Comput. Sci., vol. 13, no. 3, pp. 1259-1266, 2019.

[27] A. Saha, M. Patil, V. C. Goyal, and D. S. Rathore, "Assessment and Impact of Soil Moisture Index in Agricultural Drought Estimation Using Remote Sensing and GIS Techniques," Proceedings, vol. 7, no. 1, p. 2, 2018, doi: 10.3390/ECWS-3-05802.

[28] J. M.-V. Ivan Potić1,2, Marko Bugarski1,2, "Soil Moisture Determination Using Remote Sensing Data For The Property Protection And Increase Of Agriculture Production," 2017 World Bank Conf. L. Poverty, The World Bank - Washington DC, Mar. 2017. 